\title{
Hip Hop's Musical Horizon of Hope in Dark Times
}

\author{
Mirko M. Hall \\ Converse University \\ mirko.hall@converse.edu
}

\begin{abstract}
Prompted by the shocking death of George Floyd (who once freestyled with Houston's legendary Screwed Up Click), this short reflection explores how hip hop's revolutionary soundscapes and consciousness might serve as a utopian beacon in our dark times. It argues that this artistic movement not only creates new musical and political spaces for cultural creativity, critique, and resistance, but also continues to serve - through its Black prophetic fire - as a transformative horizon of hope that promotes both unrelenting compassion and resistance.
\end{abstract}

KEYWORDS: Black Prophetic Fire, hip hop, hope

I.

Back home in Minneapolis for my sabbatical on 25 May 2020, I never expected to be some fifteen minutes away from what would quickly become a global event: the extrajudicial killing of George Floyd, which sparked widespread international protests against police brutality as well as class and race-based injustices. The extraordinary sight of plainly dressed Wesleyans, who were protesting and singing Gospel tunes on the Stone Arch Bridge, offered the city - to riff on Dr. Dre (quoted in N.W.A 1988) - an entirely new perspective on the "strength of street knowledge". These events reminded me of my regular participation at the annual Hip Hop Studies Conference at Allen University, a historically Black university in South Carolina that is affiliated with the African Methodist Episcopal Church. In my presentations, I discussed how hip hop's hyperkinetic synergy of sound, text, and image not only creates new musical and political spaces for cultural creativity, critique, and resistance, but also continues to serve as a transformative horizon of hope for my Black brothers and sisters.

Thinking about our present historical juncture, I have come to believe that any serious scholarship on hip hop - particularly, one that advocates for its culturalrevolutionary potential - must persuade others to undertake moments of real, 
concrete social praxis. In other words, hip hop as a cultural practice and lived experience has the ability to inspire everyday people to actualize a Beloved Community that promotes both unrelenting compassion and resistance in our dark times. In this short reflection, I would like to offer some tentative thoughts following Martin Luther King's (2000: 331) call to be a "white [person] of goodwill" - on how we might harness hip hop's utopian beacon for better inclusion and equity in our divided world.

II.

Several blocks from the 3rd Precinct police station, where violent protests (fueled no less by right-wing extremists!) raged in the days after Floyd's death, I watched Swiss director Edo Bertoglio's (2000) film Downtown 81 at the Trylon Cinema in 2016. Chronicling the music scene of New York's Lower East Side in the early 1980s, the storyline follows the urban adventures of the 19-year-old artist JeanMichel Basquiat. In one particularly memorable scene, he visits a small basement party at Valentin's Social Club. Here, Kool Kyle freestyles over DJ Sinbad's scratching and cutting of an instrumental groove from Blondie's (1981) hit song "Rapture". A group of dancers, freaking to the beat in their fabulous Sergio Valente jeans, are briefly joined by Basquiat and Fab 5 Freddy (13.39-15.20).

The bona fides of this scene - the very first rap performance in a film provoked a number of audible gasps from the audience of urban hipsters. I was reminded here, once again, of hip hop's (oft-forgotten) foundation as a unique synergy of revolutionary soundscapes and consciousness. But I also thought of that brash, young real estate developer, who, at this time, was building his iconic skyscraper in Midtown and making his carefully orchestrated transition into a national celebrity. As the forty-fifth president of the United States, Donald Trump's authoritarian regime - imbued with unprecedented cruelty and white nationalist sympathies - had truly delivered, in the words of Black Lives Matter (quoted in Morrison 2016), "more death, disenfranchisement and deportations".

As a grassroots artistic, cultural, and political movement in the New York of the late 1970s, hip hop grew out of an American urban dystopia, where poverty, racism, and segregation bypassed the Civil Rights Movement. This climate was further exacerbated in the 1980s by the presidency of Ronald Reagan, whose regressive domestic policies rejected an entire generation of Black youth by foreclosing their full economic and social equality. Hip hop, however, refused to acquiesce to these conditions: its explosive sounds and philosophies - from Grandmaster Flash and the Furious Five to Public Enemy and Queen Latifah gave these young people a powerful voice to articulate their (unrealized) wants, hopes, and aspirations.

The musical legacy of Afrika Bambaataa, one of hip hop's founding fathers, is instructive here.(1) His Afrocentric youth organization, the Universal Zulu Nation, was composed of socially conscious emcees, deejays, b-girls and b-boys, and graffiti artists. It promoted hip hop's new sonorities within a cultural program of "peace, unity, love, and having fun" (Bambaataa cited in Rabin 2005), which rescued hundreds of angry youth from the streets. Bambaataa's signature electrofunk compositions not only moved his listeners' bodies, but also their minds with samples from songs like James Brown's (1968) "Say It Loud - I'm Black and I'm Proud" (Gosa 2015: 64). His politically-conscious musical events such as dance and DJ competitions helped to channel the energy of young people toward self- 
empowerment, positive social engagement, racial and gender equality, and a spirituality that recognized the human commonality of all.

Unfortunately, the pioneering work of Bambaataa and others has been often forgotten, neglected or - even worse - ignored by historical amnesia. By the mid1980s, hip hop began to grow, positively, into a global cultural phenomenon, but also, negatively for some, into a multibillion-dollar commercial industry that valorized an urban world of nihilistic gangsterism. In the latter case, whether John McWhorter's (2003) no-holds-barred critique of gangsta rap's "thuggish adversarial stance" invalidates the movement's cultural-revolutionary potential is, however, outside the scope of my reflection. I am much more inclined to agree with Michael Eric Dyson (2007), Bakari Kitwana (2002), and Tricia Rose (1994), who have eloquently defended hip hop as one of the most authentic expressions of Black experience.

To be clear, I am not attempting to re-create here the glory days of early hip hop. It can be difficult to accurately read such movements, because we are prone to interpret their contours through the lens of our own historically subjective and objective conditions. But by keeping sober analysis to the fore, we can still use the lessons of the past to better contextualize our present moment and discover new ways of looking into and changing the future. Thankfully, progressive artists like J. Cole, Kendrick Lamar, Rapsody, and Tef Poe continue to show us the way.

III.

So, what is to be done? How might a generous reading of our clip from Kool Kyle and DJ Sinbad allow us - as critics, listeners, musicians, and performers - to remix the legacy of hip hop's revolutionary poetics into even newer, more provocative grooves? How might these very vibes help us to actively resist an age that is dangerously marked by renewed crises of media disinformation, paramilitary policing, racial resentment, and social inequalities? And, given my introduction, how might we also remember the life of "Big Floyd," who, unbeknownst to many, rapped about the contingencies of life - with his deep, slow drawl - on DJ Screw's legendary mixtapes of the 1990s?

In the spirit of the countless step-by-step guides to surviving a Trump Presidency over the past four years, I would like to conclude with my own modest observations about reclaiming hip hop's compelling message of hope.

One: We must remember that early hip hop was, above all, a democratic community-building movement. It involved the creation of a politically-charged artistic vision that moved beyond disenfranchisement to advocate for social justice and change. We must commit ourselves to the building of a community of like-minded enthusiasts, particularly, with local independent artists, who uphold the tradition of hip hop as a movement for actualizing everyday change. We must also embrace the genre's ever-expanding DNA of cross-cultural and multi-racial collaboration as the true reflection of contemporary American society.

Two: We must remember that early hip hop laid the foundation for a new incarnation of revolutionary funk: a keen awareness of the experience of Black suffering that becomes - through its radical transvaluation under love and grace a powerful force of compassion and resistance. We must continue to harness hip hop's moral imperative or what Cornel West (2014) calls its "Black prophetic fire". In other words, we must maintain a hypersensitivity to the suffering of others, which has the courage to always speak the truth - even in the face of 
danger - about social injustices, while never failing to strive and hope for positive change.

Three: We must remember that early hip hop celebrated - against the forces of personal prejudice and institutionalized discrimination - the richness of Black experience. In keeping the faith, cultural critic Lawrence Ware (2017) implores our Black brothers and sisters to "remember to live. Not exist; live. Thrive. Be unapologetically black and unremittingly brilliant". In a similar manner, activist Mervyn Marcano calls on me and other white people to be "complicit in dismantling racist structures by taking risks, putting [our] bodies on the line in the streets, sharing access to resources ..., living in some discomfort with difficult conversations in collaboration, [and] knowing when to listen" (quoted in Kohn 2015). In doing so, however, we must allow our Black friends to organize the content and context of any social justice pursuit.

IV.

In harnessing the revolutionary power of early hip hop, we must re-actualize its radical critique, which calls out the continued suffering of Black America without compromise, but always remains positive by continually projecting alternatives to the denigration of its spirit. By seizing the emancipatory impulses of early hip hop, and re-mixing them for our new dark times, we have the chance to create a musical horizon of hope, which has - in the here and now through the continued remembrance of past struggles - the capacity to transform our contemporary society into a more humane and just world.

Musical movements like hip hop may not always engender revolutions, but they do create - through affective flows and cognitive waypoints - real spaces of cultural resistance, however limited and momentary, for individual and collective freedom. Let us, then, continue that wonderful journey, which hip hop inaugurated some forty-five years ago. And let us also remember those words that Jesse Jackson (2000: 78) sounded off at the Democratic National Convention in Atlanta in 1988: "It gets dark sometimes, but the morning comes. Don't you surrender! ... America will get better and better. ... Keep hope alive!"

\section{Endnotes}

(1) I am keenly aware of the lawsuit, which was filed in August 2021 in New York State Supreme Court, that accuses Afrika Bambaataa and the Universal Zulu Nation of sexual abuse and sex trafficking in the 1990s. Notwithstanding Bambaataa's pivotal role in the historiography of hip hop, these allegations are deeply troubling.

\section{Acknowledgements}

I greatly benefited from my conversations with organizer Kevin Trumpeter, emcee/journalist Preach Jacobs, and a cohort of very engaged students at the Hip Studies Conference at Allen University in 2016, 2017, and 2019. Thank you to Seth Howes, Martin Law, and Naida Zukić for their comments on this reflection. 


\section{References}

\section{Bibliography}

Dyson, M. E. 2007. Know What I Mean?: Reflections on Hip Hop. New York: Basic Civitas.

Gosa, T. L. 2015. The Fifth Element: Knowledge. In J. A. Williams Ed. The Cambridge Companion to Hip-Hop. Cambridge: Cambridge University Press: 56-70.

Jackson, J. L., Sr. 2020. Common Ground. In G. J.-S. Kim Ed. Keeping Hope Alive: Sermons and Speeches of Rev. Jesse L. Jackson, Sr. Maryknoll, N.Y.: Orbis: 6378.

King, M. L., Jr. 2000. Some Things We Must Do. In C. Clayborne et al. Eds. The Papers of Martin Luther King, Jr. Volume 4. Berkeley: University of California Press: $328-343$.

Kitwana, B. 2002. The Hip Hop Generation: Young Blacks and the Crisis in African American Culture. New York: Basic Civitas.

Kohn, S. 2015. This is What White People Can Do to Support \#BlackLivesMatter. The Washington Post, 6 August. https://www.washingtonpost.com/ posteverything/wp/2015/08/06/this-is-what-white-people-can-do-to-supportblacklivesmatter/ Accessed 15 June 2021.

McWhorter, J. H. 2003. Rap Only Ruins. Manhattan Institute, 10 August. https:// www.manhattan-institute.org/html/rap-only-ruins-0178.html. Accessed 15 June 2021.

Morrison, A. 2016. Exclusive: Black Lives Matter Issues A Statement on Trump's Election. Mic, 15 November. https://www.mic.com/articles/159496/exclusiveblack-lives-matter-issues-a-statement-on-trump-s-election. Accessed 15 June 2021.

Rabin, N. 2005. Afrika Bambaataa. The A.V. Club, 2 March. https://www.avclub. com/afrika-bambaataa-1798208451. Accessed 15 June 2021.

Rose, T. 1994. Black Noise: Rap Music and Black Culture in Contemporary America. Middletown, Conn.: Wesleyan University Press.

Ware, L. 2017. A 5-Step Guide to Surviving a Trump Presidency. The Root, 21 January. https://www.theroot.com/a-5-step-guide-to-surviving-a-trumppresidency-1791438831. Accessed 15 June 2021.

West, C. 2014. Black Prophetic Fire. C. Buschendorf Ed. Boston: Beacon.

\section{Discography}

Blondie, 1981. "Rapture". Chrysalis Records, USA.

Brown, James. 1968. "Say It Loud - I'm Black and I'm Proud". King Records, USA. N.W.A. 1988. Straight Outta Compton. Priority Records, USA.

\section{Videography}

Downtown 81. 2000. Dir. Edo Bertoglio, New Beat Films. 